\title{
THE PUBLIC PAPERS AND ADDRESSES OF FRANKLIN D. ROOSEVELT
}

\author{
HaROLd J. LASKI*
}

7 HESE stately volumes represent an interesting and illuminating innovation in the public life of the United States. They contain

1 not merely all the more important state papers and addresses of Mr. Roosevelt's administration, but each of them is annotated by the President himself; and there is also an ample, and largely verbatim, selection of the Press Conferences at the White House which have been so significant a feature of the Presidency since I933. We are thus able, as it were, to see Mr. Roosevelt at work in his more public context. We catch glimpses of the inner personality, of the man who, in himself, has been so outstandingly the driving force of his administration. As a revelation of the dynamics of the greatest democratic institution in the modern world, the volumes are of incomparable value. As an insight into their working, I know nothing of similar importance save that unique Diary of John Quincy Adams which, even yet, has not received its proper recognition by students of the social sciences.

There are many points of view from which these volumes could be discussed. They are a portrait of Mr. Roosevelt himself. They are a revelation of the range of the Presidential function in its daily operation. They are a clue to the changing contours of American life, both in its national and in its international aspects. They are a clue, further, to the purposes of the present administration at an epoch of American history that is, on any showing, vital. It is not easy for a foreigner to comment upon these things; however delicately he tread, like Agag, he runs the risk of being torn in pieces. If I venture, therefore, to move over dangerous ground, the fault must be attributed less to my own temerity, than to the editorial sense of a fitness which I have not had the courage to call into question.

The outstanding qualities of the President that these papers reveal are first, courage, and, second, the experimental temper. I venture to doubt whether he has, beyond a general faith in the rights and virtues of the common man, any considered and systematic philosophy. He is immensely aware of the power of, and need for, state-action. He conceives that it must be unfailingly applied to mitigate the consequences of social

* The London School of Economics and Political Science. 
and economic hardship. He conceives it, as I understand him, as a weapon to supplement and correct those actions of individuals about the large pattern with which he is, on the whole, content. He is a liberal, in the positive sense; he is in no effective sense a socialist. His liberalism seeks to deal with a mass of particulars; it does not drive into the roots from which those particulars would seem, to an outsider, to derive. He has no doubt of the inherent adequacy of the traditional American institutions; it is for their adaptation, rather than for their reconstruction that he is concerned. There is even a sense in which, after Edmund Burke's fashion, he may be regarded as a Conservative. "Reformation," he seems to say, "must proceed upon the principle of reference to antiquity." His liberalism is born of two things. In part, it is the aristocrat's compassion for the little man battling against immense economic forces beyond his control; in part, also, it is his sense that a period of rapid change involves rapidity of institutional adaptation if the commonwealth is to be secure. He reforms in order to preserve. He does not seek change because he denies either the validity or the virtue of the inheritance. There is not an atom of the revolutionary either in his temper or in his ideas. Even his explosions of generous indignation represent rather the disgust at abuse than the sense that the excrescences he seeks to remove may be an essential element in the body social.

He has courage, I have said, and the experimental temper. No one can read speeches like the First Inaugural, or the proclamations of the first few months, the messages recommending the Securities Act, the Public Utilities Act, the Social Insurance measures, and doubt that courage. The experimental temper comes out in a score of ways, hardly less, perhaps, in the failures than in the successes. It is not the least obvious in those diffcult days when the President was seeking-mistakenly, I think-to salvage something from the fateful decision of the Supreme Court in the Schechter case. It is the persistency of these qualities which distinguishes him from Woodrow Wilson and Theodore Roosevelt. Mr. Wilson had great courage; but by IgI4 the experimental impulse in him was exhausted, and, outside the international sphere, the record of his administration was a barren one. Throughout his period of office, Theodore Roosevelt had immense verbal audacity; but there is nothing in the objective record of achievement of corresponding significance. Franklin Roosevelt, as the Wages and Hours Act of the last Congress makes clear, is not deterred by failure from persistent pursuit of the changes he has deemed necessary. He may not tread a straight path; he may move by a labyrinthine circuit of advances and retreats, some of them, at least, 
inexplicable to the outsider. But the main impact of these three thousand pages is of a man who, behind all the shiftings and twistings which the American political system imposes on any President, remains steadfast to a body of purposes which come clearly through the whole effort. He commands, he persuades, he cajoles, he warns, he threatens; the variety of his artifice corresponds to the complexities of his situation. Yet that variety is less the expression of inner uncertainties in the man than of the need of the captain to take a huge vessel through difficult and largely uncharted seas; to take it, moreover, upon the sovereign condition that the crew, as it were, must be persuaded to co-operate in the fulfilment of his sailing orders.

Anyone who reads the press conferences set out here will note certain other qualities of importance. The President has imagination, a sense of humor (a supreme need in a democratic statesman), an inner self-confidence born, no doubt, of triumph over physical difficulty, but vital in its result for the attainment of a spiritual equilibrium. There is an omnipresent sense of the greatness of his task; there is no pontificality about the manner of its fulfilment. He can be dramatic; I have found only rare instances where he is theatrically rhetorical. He has an amazing power of adjusting himself to the particular audience he seeks to persuade. Granted all that is done for him by his associates, his own insights into the material he has to handle are extraordinarily impressive in their range. Sometimes, I think, the grip relaxes; on currency questions, for instance, I doubt whether the President could stand up to a close cross-examination from so dexterous a dialectician as Professor Lionel Robbins. But where he is speaking less to a brief that he has mastered, and more from long experience painfully garnered, on public utilities, for example, on the insecurity of the wage-earner, on the reactionary forces in business enterprise, on conservation, he speaks from a full mind and a full heart. He has the power of significant phrase, the gift of happy illustration, the quality of directness in approach that seizes his reader at once of the essence of the thing he is seeking to say. Not least among these personal qualities I would mark the gift of generosity. That is evident in a hundred instances where he picks out the work of some associate for praise, or makes a group of his coadjutors realize his own sense of his dependence upon the quality of their co-operation. Here, I think, is one of the supreme secrets of Mr. Roosevelt's success. For that quality of generosity impels the giving of confidence; and it creates in the men who work with him a sense of team-work, of joint adventure, that is essential to achievement.

"A democratic Statesman," Bagehot has somewhere written, "must be 
an uncommon man of common opinions." If he is ahead of the masses, he must never be so far ahead that they cannot enter with sympathy into the fulfilment of his task. A lonely President, an excessively sensitive President; a President who sees too far into the future and is obstinately determined to act upon insights the common man does not understand, is unlikely, save in the exceptional instance, to be a successful President. Here Mr. Roosevelt's own temperament is an important safeguard against disaster. He enjoys contact with his fellows; there is no sort of aloofness about him. He can take criticism without repining; his self-confidence is not destroyed by defeat. The principles for which he stands are, overwhelmingly, those of the classical progressive tradition in America; there is nothing strange nor unexpected about them save in the instance of the Court proposals. There, is it interesting to note, while he sought an objective intelligible to, and sympathized with by that great majority which gave him power, he sought its achievement by ways with which the tradition had not familiarized the masses. He was too ingenious, both in concept and in mechanism, for a multitude which sees the broad highways only. He had insufficiently prepared it for the circuitous divagation from that highroad. It is the only instance I can find here in which his hold of the opinion upon which he depends was unsure in method and inadequate in execution. I suspect that when the secret history of the Court proposals comes to be written, we shall find that no small part of that defeat was the outcome of lesser men's urgency prevailing over his own normal realization that the way to win the confidence of the people is to take them into your confidence. On the Court fight, he was not in a realm made familiar to him by technical experts; and he made the mistake, I suspect, of relying upon advisers who did not understand that no statesman can ever successfully attack fundamental institutions by sidestepping them. It says much for his resilience that he has had the capacity to recover from a defeat as resounding as any President has suffered.

The President of the United States is King and Prime Minister in one; not the least interesting aspect of these pages is, for an Englishman, the light they throw upon so unique a combination. To be ceremonial head of the state; to be the source of all legislative proposals and of executive decisions; to combine these with the continuous need to be at once the head of the nation and the leader of his party; the call made upon a single man by the qualities these varied functions require is on any showing immense. The President may one day be accepting a portrait of George V for the National Gallery at Washington. He may be sending the Securi- 
ties Bill to Congress with an appropriate message. He may have to greet the Daughters of the American Revolution, on one day, and the National Education Association on the next. Washington's birthday calls for one kind of speech, and Jefferson's birthday, from a Democrat, for another. There may be a statement on the situation in the sugar industry, a message to boy-scouts, an executive order establishing the National Resources Board, a proclamation on the coinage of silver, a letter to a senator refuting charges made of discrimination among the press. The mere range of the functions is momentous. When there is added to them the pressure of the stream of callers, the necessary conferences, the task of handling Congress, the need to watch and to guide the opinion of the public, the control, with all its consequences, of the international relations of the United States the operation of the immense, and heart-breaking, power of appointment, the wonder, to an outsider, is that a President ever gets the chance, at least in a coherent and orderly way, to think out the substance of his policy.

For it is not merely the range of function; it is also the pressure under which decisions have to be taken, and the immense responsibility which attaches not least to those which have to be taken most rapidly. All this impinges the more profoundly upon a President who, like Mr. Roosevelt, has a positive conception of his function. He may get some aid (I doubt whether Mr. Roosevelt has had much) from his cabinet; he may get some more from those trusted advisers in non-official positions upon whom, it is probable, the modern President is coming more and more to rely. No doubt, too, the presence in Congress of a group of trusted politicians, of whose impact upon both Houses he can be sure, counts for a great deal; it relieves the sense of an ever-constant need for unrelaxing vigilance at the Capitol. But, when all possible deductions have been made, there is no problem of which it cannot be said that it may be material upon which the President, and no one but the President, must make up his mind. Upon most of them he cannot hope to be an expert. Upon most of them, also, the people will look for some pronouncement from him; and upon most of those pronouncements he must expect the most expert criticism that opposition can produce. For it is by that criticism that opposition hopes to replace him. Nothing that he can do is immune from public scrutiny; he knows that, however good his intentions, all that can be said against his policies, legitimately and, not seldom, illegitimately, will be said.

What are the qualities called for by so vast and so intense a range of functions? Above all, I think, the power to handle men, the ability al- 
most intuitively to recognize, as Mr. Roosevelt recognized when he appointed Mr. Ickes the Secretary of the Interior-the efficient human instrument for his purposes. There is the need to come to office with a general sense of the direction in which he wishes to move. He must be able to think and decide rapidly, and to have the pertinacity to abide by his thought and decision. There is the ability to co-ordinate, which largely depends on the power to recognize the difference between the significant and the insignificant. The President who cannot delegate, and trust when he has delegated, is lost. He must know how to get into touch with the masses. He must have the sense of time; the art of effective delay is not less important than the art of dramatic action. He must be able to lose himself in the bigness of his task; and yet he must remain sufficiently aloof from it to be able to judge himself soberly in the midst of the passionate judgments that will be made about him. He must be steadfast in his purposes, yet never so obstinate that he cannot adapt them to the pressure of events. He must realize that while, to some degree, he is making history, he can never make it, as Marx said, out of whole cloth; for the vast impersonal changes woven by the forces of production will always, in the long run, define the road along which he must travel. $\mathrm{He}$ must be able to make articulate the inner aspirations of ordinary folk; and he must realise that the best way to achieve this end is so to inspire ordinary folk that they are led to articulateness by his activities. A President must never lose the common touch, but he must never be controlled by it.

The office, on any showing, demands an extraordinary man; and it is a commonplace that, with perhaps nine exceptions, the office has not called forth extraordinary men. The occasions, indeed, when it has not added to the stature of its occupant are rare; and perhaps still more rare are the times when experience has not been synonymous with growth. That was notable, above all, in the two great Presidents before the contemporary epoch-Jefferson and Lincoln; I think it has been evident, also, in Mr. Roosevelt's own incumbency. To some extent, too, it is apparent that, in the tradition of America, extraordinary times have called forth extraordinary men. That was true in 1789 ; it was true in 1800 ; it was true, again, in I86I and I933. But a foreigner who reads these volumes, and seeks to learn the lesson of their implications, cannot avoid the uneasy sense that the system by which the President of the United States is chosen is not adequate to the qualities the office demands. The system is a lottery; and, as Bagehot said, success in a lottery is no argument for lotteries. A weak President in the crisis of r933 would have been an irrep- 
arable disaster; and it is largely accident that the Democratic convention of $193^{2}$ did not choose a weak President. A great democratic leader must be something more than the most available man. He must impose himself by his positive qualities; the system, at least in normal times, tends to make positive qualities a hindrance to, rather than an asset for, choice. In too few cases is the selective process which precedes nomination long enough or rigorous enough, as in the House of Commons it is both long and rigorous, to have proved the fitness of the aspirant. No democratic people can afford any prolonged succession of Hardings and Coolidges. No party in defeat can recover office unless its Presidential candidate has something significant to say.

These volumes, as I have said, are a clue to the changing contours of American life, both national and international. In the first aspect, they mark the final emergence into the American tradition of the positive state. A foreigner cannot, of course, judge how far the implications of this step are understood in America. Mr. Roosevelt himself not seldom speaks in these pages as if the form of the present Constitution is, adequately interpreted, suitable to the immense demands that will be made in the next few years upon its institutional expression. I venture, with profound respect, to differ from this view. The positive State is the outcome of the maturity of giant capitalism. Its problems call for uniformities, both in legislation and in administration, to which the genius of a federal system is strange. It can accommodate itself to a fairly wide decentralization, on the condition that the powers so distributed can be amended by central determination. But, neither functionally nor financially, can it accommodate itself to a system in which the authority of the central power is not only inhibited by a technique of distribution long outmoded, but one, also, in which the Supreme Court and the States themselves may well present a front of reactionary obstinacy to vitally necessary change. Federalism, I suspect, is a scheme of government which suits the habits of a state which is still in its youth; it is not suited to the habits of one that has definitely attained maturity. It is not merely that the States, as areas of government, are irrelevant to the profounder problems of America; it is also that they have accreted to themselves habits, ideas, interests, idiosyncrasies, that gravely impede the central purposes of good government. When, in any national life, the relations of production begin, as in America they have begun, to be out of harmony with the forces of production, one of the necessary inferences to be drawn is the need for drastic revision of the fundamental structure of government. I believe myself that the time for that revision is due in the United States. It is postponed, partly 
because the immense achievements of the Constitution in its earlier phases act psychologically to prevent the recognition of its central defects; and, partly, because those very vested interests, the operation of which reveals the contradiction between the forces and the relations of production, have associated their fortunes with the Constitution in its present form. Their dynamic is its dynamic also; no alteration can be made in the one without necessary and profound consequences to the other.

On the international side also, for good or ill, the fortunes of the United States are inescapably intertwined with those of the older world. A change in the technique of cotton production in the South may permanently alter the life of an Indian ryot in the province of Bombay; a victory in the Far East, by either China or Japan, is bound to have immense repercussions upon American economic life. So long as the distribution of wealth in the United States compels it to set its standard of life by the markets it can conquer abroad, her statesmen cannot, in matters of major significance, pursue over any considerable period of time a policy of isolation. In a world-fight for power neutrality is a concept of academic thought and not a reality of political maneuver. Isolationism would mean such a revision of the foundations of American economic life as probably to involve internal strains hardly less than those which divided America in the generation preceding the Civil War. The policy of the "good neighbor," as Mr. Roosevelt terms it, involves reciprocity of habit. It has still to be shown what its effectiveness is when its intention is tested by non-reciprocity on the other side. Could an America, for example, watch, vowed as it is to democracy, the increasing fascization of Europe and the Far East, with the imperialist policy involved in that increase, and remain in aloof neutrality from its consequences? Obviously, this is a question which Americans only can answer. But, in answering it, they have to consider not merely their subjective devotion to peace; they have to consider, also, the objective impact upon themselves of states whose purposes traverse their own fundamental purposes. It is enough for a foreigner here to point out that every item in the defense policy of the United States is necessarily determined by the network of international relationships in which it is involved. From that determination there follow consequences in large part independent of the will to peace in individual citizens, however numerous. The state-power, as state-power, has laws of its own which it must fulfil if it is to survive as state-power.

It is, I think, in some such background as this that the policies of the Roosevelt administration must be set. These volumes throw a clear light upon their inner structure. Much of them, it is evident, have been born, 
almost haphazard, of imminent and imperative danger; they are improvisations of the moment rather than permanent policies. Others, again, are the ultimate deposit of a long tradition in American history. No reader of these pages can fail to note how large a part of the long-term measures in the Roosevelt administration attach themselves historically to the roots of that Progressive movement which reaches back to the turn of the century and beyond. The evils of monopoly, monetary instability, economic insecurity, financial malpractice, these are not new themes. Most of them were spoken of with vehemence by Theodore Roosevelt; some of them, most notably in the realm of banking, were dealt with impressively by Woodrow Wilson. Even the attack upon the Court was new in method rather than in theme; and, as in $19 \mathrm{I2} 2$, the popular revulsion from the Court was followed, at an interval sufficient to suggest intellectual reflection rather than emotional adjustment, by a shift in the axis of the Court's thinking. What is new in these themes is not their substance but their urgency. What in the New Deal is new in the treatment of them is less the manner than the continuity and the persistence with which they have been attacked.

It is not, of course, for an outsider to pass judgment upon the policies of Mr. Roosevelt; that is a theme too controversial for foreign examination in this place. I would venture only upon one remark of a general character; and upon certain conclusions of a psychological kind which do not approach the question of their validity. The general remark is that a large part of Mr. Roosevelt's approach to his problems is conditioned by the belief that the pathology of American economic life is occasioned by the malpractices of evil men; and from this he draws the general inference that it is in the power of legislation, wisely administered, to correct those malpractices. The American economic system, he seems to say, is, in itself, sound in conception; his function is that of a physician who restores by his art the conditions of a healthy metabolism. I am not myself able to accept this diagnosis. It seems to me built upon a separation between theory and practice for which there is no logical validity. A national system is what it operates as being. The malpractices against which President Roosevelt has inveighed so eloquently are not the work of evil men, but the immanent logic of its inherent nature. Competition does not give place to combination because a few wilful men wish it to be so; it is outmoded because thereby the logic of capitalist ownership is fulfilled. On its own plane of concept, the answer of the state to capitalism is not more intervention, but non-intervention. For an interventionism which seeks to maintain at once private ownership in the means of production, ade- 
quate living conditions for the masses, power to make profit in national and international competition, will find these things in the long run incompatible with the democratic basis of the state. There are American writers of distinction (as there are European writers) who have seen that this is the case, who have, accordingly, pleaded for a return to non-interventionism, and built their plea upon the concept of a neutral state, which stands without bias between the contending parties in the economic realm. For reasons too long to develop here $I$ believe there is no substance in this view. The concept of freedom of contract is devoid of meaning, as Mr. Justice Holmes so often insisted, unless there is equality of bargaining power; in its absence, a political democracy will always insist on increasing intervention to secure mitigation of the results of its absence. Historically, moreover, the state in operation is not, and cannot be, a neutral factor in society. The state is de facto government; and it operates to secure the interests of those who, in society, own, and live by, the instruments of production in society. To make a neutral state, there must be an equal interest among citizens in the results of its operation. There cannot be that equal interest so long as the instruments of production are privately owned.

The psychological results of the Roosevelt epoch must strike any foreigner who knew America before his advent to power; and there is a sense, I think, in which these results may be the most permanent consequence of his tenure of office. Those to which $I$ wish to draw attention are four in number. The first is the creation, especially among the workingclasses, of what Mr. H. G. Wells has termed a "sense of the state." Mr. Roosevelt has altered and advanced the level of legitimate expectation of satisfaction posed to the rulers of America by citizens. He has ended the era in which politics seemed outside men's lives. What is done at Washington has become to the farmer, the industrial laborer, the white-collar worker, significant in his life. The federal government, out of this new sense, has been compelled to assume immense responsibility for the material well-being of the masses in proportions that are new in American history.

Out of this "sense of the state" there has been born, second, a political education for the common man, an interest on his part in the governmental process in which he is involved, that, again in its proportions, is both new and important. Organized labor and American youth have a consciousness of the need to understand the society to which they belong. That consciousness, no doubt, is very largely the outcome of the grave

I I have sought to point them out in my State in Theory and Practice (1936). 
problems they confront; the land of opportunity has now had, for approaching a decade, something like ten millions of unemployed. What Mr. Roosevelt has done is to awaken in them not merely the sense that the state is, by political right, theirs, but, even more, that they have to train themselves to formulate the purpose for which it is theirs. There is, I think, a profounder and more sustained interest in politics in the United states today than at any time since the Civil War. And it is notable that, crude as it often is, it is not an opinion easily controlled by professional propagandists; the election of 1936 is a sufficient commentary upon the abyss which now separates public opinion and newspaper opinion. It is too much to say that this is a permanent gain; it might easily be dissipated if economic catastrophe were to attend Mr. Roosevelt's policies. But, short of that, it is a vital change. It is the end of the epoch of "rugged individualism" in America. It has taught literally millions that they are members one of another. It has made the community of which they are a part a living element in their consciousness in a way that has not previously been known. And that consciousness, above all, has been quickened where it most needed activity, among the laboring section of the people. From this angle, the Roosevelt era marks an epoch in American history.

One other element, if smaller in volume, is none the less significant in its future influence. The intellectual has, since 1933, come to occupy a qualitatively different place in American life from anything previously known save in the brief period of Virginia's pivotal influence in the last thirty years of the eighteenth and that of Massachusetts in the second third of the nineteenth centuries. This is the outcome of three predominant causes. In part, it is result of the final achievement of American cultural independence; the ethos of American thinking now has its roots in American soil and is therefore more relevant to specifically American civilization. In part, it is the outcome of a crisis of world-importance which has made philosophies more actual and living than they seemed in an age of security; their exponents, therefore, have an audience more eager to listen to ideas. In part, again, it is due to the fact that the intellectuals themselves realize increasingly the futility of a theory divorced from action. To think is to be responsible for the deed; to dwell aloof in the ivory tower is to shrink from responsibility for the consequences of thought. When that happens, power goes to the men who have habit without philosophy; to give them power in an epoch of crisis is to assure the suppression of philosophy since habit is the enemy of all thought that seeks the formulae of creative change. The result of the changed place of 
the intellectual can be seen in many ways. Partly, it is visible in the personnel of the Administration itself; for the first time in many a year the departments in Washington are full of young men with ideas. Partly, also, it is evident in the changing attitude to government service. The young lawyer who, a decade ago, thought naturally and comfortably of Wall Street or State Street as his natural spiritual home, now thinks of government service as a more creative avenue for his ability. Partly, once more, it is seen in the slow emergence, above all in jurisprudence, of a new and critical temper towards traditional social thought. In a civilization geared to the framework of a legal document, the significance of this renovation does not require elaborate emphasis. But it is, perhaps, worth emphasizing that the influence of Holmes and Cardozo, Stone and Brandeis, among the judges, of Frankfurter and Morris Cohen among the academic lawyers, would not have been possible in the America of the last generation.

The final element in this psychological impact to which $I$ wish to draw attention is not American only in its influence; rather has it been worldwide in its implications. Since 1933 , we have mostly been accustomed to a democracy seemingly in slow process of grim erosion; it has been uncertain of itself, unable, accordingly, to seize its opportunities, bewildered about its values, and slow to meet its emergencies. The America of Roosevelt has offered a heartening contrast. No one, I think could reasonably say that it has fully met, much less overcome, any of its central problems. No one either could reasonably deny that its approach to them has been affirmative and not negative in character. In five breathless years, it has lived the intensity of a generation. Men have had the sense that something was being done. They have been given the exhilaration of hope. They have been shown that a people can, if it is adequately led, move swiftly to action without losing the democratic right to be the master of its own destiny. The American remains a citizen capable of deliberately willing change; he has not, as in Fascist countries, become the inert recipient of orders that he must obey without scrutiny under sanction of the concentration-camp. If our age emerges successfully from this period of blood and iron, I believe that the Roosevelt experiment in America, with all its blunders and follies, will be regarded by the historian as having made a supreme contribution to the service of freedom. For it will have shown, in that event, that the principle of responsible and democratic self-government has still enough vitality left to persuade men to die and, even more, to live for the fulfilment of its objectives. "We do 
not distrust," said Mr. Roosevelt in the First Inaugural, "the future of essential democracy. The people of the United States have not failed. In their need, they have registered a mandate that they want direct, vigorous action. They have asked for discipline and direction under leadership." They have had that leadership in a fuller sense than any of the old democracies of Europe; so far, they have responded to it in ample measure. If they continue that ardor of response, it may well be that it will become the splendid destiny of America to save Europe by her example as she will have saved herself by her energy and her determination. 